\title{
AESTHETIC COGNITION OF SOCIETY Modern and postmodern representations in contemporary non-fiction
}

\author{
Paulo Tiago Bento \\ Universidade Federal do Sul da Bahia
}

\begin{abstract}
Patterns of representation in travel writing, travel guides, journalism and memoir are shown to amount to aesthetic cognition by comparison to social science analogues. Their postmodernity questions the supposed factuality of those genres. Travel writing and travel guides's expected orientation to the present is contested by how the past is used. The patterns show operational potential for empirical testing of usual temporal boundaries of the postmodern. Finally, they are forms of modern and postmodern cognitive engagement of tourists and would-be tourists with society, complementing major theories of tourist motivation.
\end{abstract}

Keywords: aesthetic cognition, postmodernism, tourism, travel writing.

Cognição estética da sociedade. Representações modernas e pós-modernas em textos não ficcionais contemporâneos

Resumo Demonstra-se que certos padrões de representação nos géneros literatura de viagem, guia de viagem, jornalismo e memória constituem cognição estética, ao compará-los com padrões análogos usados nas ciências sociais. A pós-modernidade dos padrões questiona a suposta factualidade desses géneros. A esperada orientação da literatura de viagem e dos guias de viagem para o presente é posta em causa pela forma como o passado é usado. Os padrões revelam potencial operacional para testar empiricamente os limites temporais habituais do período pós-moderno. Finalmente, são formas modernas e pós-modernas de relacionamento cognitivo com o social por parte de turistas e aspirantes a turistas, complementando as principais teorias de motivação turística.

Palavras-chave: cognição estética, pós-modernismo, turismo, literatura de viagens.

Cognition esthétique de la société. Représentations modernes et postmodernes dans des textes non fictifs contemporains

Resumé Il est démontré que certains schémas de représentation dans les genres récit de voyage, guide de voyage journalisme et mémoires constituent cognition esthétique, en les comparant avec analogues dans les sciences sociales. Leur postmodernité met en question la factualité supposée de ces genres. Les récits de voyage et les guides de voyage utilisent le passé de manière inattendue si on considère qu'ils sont censés être centrés au présent. Les schémas montrent potentiel opérationnel pour le test empirique des limites temporelles usuelles de la période postmoderne. Enfin, ce sont des formes modernes et postmodernes d'engagement cognitif entre touristes et touristes potentiels avec le monde social, et ils complémentent les principales théories de la motivation touristique.

Mots-clés: cognition esthétique, postmodernisme, tourisme, écriture de voyage.

Cognición estética de la sociedad. Representaciones modernas y posmodernas en textos no ficcionales contemporáneos

Resumen Se demuestra que ciertos patrones de representación en los géneros literatura de viaje, guía de viaje, periodismo y memoria constituyen cognición estética, al compararlos con patrones análogos usados en las ciencias sociales. La posmodernidad de los patrones cuestiona la supuesta factualidad de esos géneros. La esperada orientación de la literatura de viaje y de las guías de viaje al presente es cuestionada por como utilizan el pasado. Los patrones revelan potencial operacional para probar empíricamente los límites temporales habituales del período posmoderno. Finalmente, los patrones son formas modernas y posmodernas de relación cognitiva con lo social por parte de turistas y aspirantes a turistas, complementando las principales teorías de motivación turística.

Palabras-clave: cognición estética, posmodernismo, turismo, literatura de viajes. 


\section{Introduction}

Representations of people and societies are important building blocks in the social construction of reality, shaping attitudes and practices, with travel writing, travel guides, journalism and memoir often playing significant roles. This study highlights patterns of representation within these genres that aestheticise cognition of society, providing a novel way of looking at tourist motivations in light of the modern/postmodern framework, with broader implications in as much as tourism is a cultural indicator for society at large (MacCannell, 1999 [1976]).

With the benefit of textual examples, an empirical-based discussion of the concept of aesthetic is performed. Specifically, aesthetic cognition of society consists in cognitive relations regarding social dimensions where the validity or the relevance of knowledge is at least partially dismissed, falling into a postmodern dissolution of boundaries (Urry, 2002 [1990]) - in this case between valid/invalid and relevant/irrelevant.

If postmodernism is taken as an intellectual practice characterized by such dismissal, aesthetic cognition of society becomes an instance of postmodernism. Given the operational potential of the patterns, future studies could work out their frequency in texts produced at any epoch as a way of dealing empirically with the issue of whether postmodernism is a mental attitude or practice rather than a historical period (Eco, 1985; Lyotard e Massumi, 1986), helping to overcome frequently vague, non-operational definitions of postmodernism.

A first case of aesthetic cognition of society is called presentification of the past. It consists in references to past events or states of affairs having as pretext the fact that an author is at or making reference to a place where such events or states of affairs took place. Such somewhat arbitrary inclusion of the past in texts produces the "perpetual present" characteristic of postmodern culture (Jameson, 1983: 125, quoted in Plummer and Nehring, 2014: 180), while, paradoxically, it can amount to a grand narrative - the absence of which defines postmodernism for Lyotard (1984). Albeit the pattern is frequent in travel writing and travel guides, no systematic account of it has been presented before.

A second case is synecdocal imagination: it consists in taking particular, observed elements of a society as signs of a whole society without attention to the validity of the generalisation. The third case, called the inconsequential social, is made up of information about the social world that provides no relevant knowledge of such world. The fourth, fragile social causality, connects two situations (at least one with a social dimension) by a suggestion of causality that is unfounded, unclear, unlikely, and/or impossible.

The patterns also help detailing some of the most influential theories of tourist motivation, ${ }^{1}$ which see tourist trying to escape confusion and anomie in daily life and seeking, inter alia, for social interaction. MacCannell (1999 [1976]) holds that tourists search within otherness for authenticity lost within modernity and a way of performing such search, this study shows, is by engaging with the patterns

1 For a recent thorough review of the literature on tourists' motivations see Li Zhang and $\mathrm{Ca}$ (2016). 
as reader. Cohen (1979) criticises MacCannell by noting that tourists differ considerably from one another in their motivations and proposes a phenomenology of tourist experiences. Here, the cognitive relations underlying the patterns can play different roles: in the recreational mode (performed within one's own society) and the diversionary mode (performed elsewhere), tourists look for entertainment; in the experiential mode (searching for alternative meanings within otherness), experimental mode (sampling different life styles) and existential mode (stronger, stable connections with otherness) tourists look for meaning elsewhere. Given Cohen's phenomenology can be seen as a particular case of Iso-Ahola's (1982) model of motivation (which approaches tourism as a way of escaping everyday problems), the patterns also help detailing this model, which includes a personal dimension (troubles, difficulties and failures) where rewards of travelling include feelings of mastery, learning about other cultures, ego-enhancement and prestige.

In addition, aesthetic cognition of society helps explaining the interest and curiosity underlying the tourist gaze (Urry, 2002 [1990]), and further includes cases where no physical contact with otherness takes place (de Botton, 2002) and where relations to otherness are non-visual. Finally, the patterns highlight the problematic definitions of travel writing and travel guides as factual and focused on contemporary journeys. They do so by identifying a frequent and significant presence of the past and aesthetic cognition within these genres, and suggest that the phenomenon may also be important within journalism and other non-fiction.

\section{Methods and materials}

The media are well known as shapers of visions of reality, being often crucial in providing access to places that direct experience does not provide contact with. Specifically, travel writing and travel guides produce representations that play important roles in relations between peoples and in tourist's choices and perceptions regarding destinations (for example, Mercille, 2005; and Santos, 2004). These two genres are thus used as evidence, to which adds a few cases in journalism and memoir.

This study does not perform surveys on tourists, such as in Ross and Iso-Ahola (1991), who apply Iso-Ahola's model (1982). Texts are deemed more suitable because tourists may be unwilling and/or unable to reflect and/or express travel motives (Dann, 1981). As Malinowski (2005 [1922]: 17) puts it, "people usually do feel or think or experience certain psychological states in association with the performance of customary acts, [but] the majority of them surely are not able to formulate these states, to put them into words". On the other hand, observing individuals acting is usually not useful when trying to reach meaning, as meaning is something ascribed to an act by the agent.

As usual in the analysis of texts, examples are quoted and commented. Their significance is considered in qualitative terms and the presentification pattern is further subjected to quantitative analysis, given its high frequency. This is applied, as regards travel guides, to a random sample of two major series in English - 
Lonely Planet ( $L P$ ) and The Rough Guides (RG) - is considered. The sample does not intend at full representativeness of the genre, aiming instead at presenting cases for analysis and suggesting widespread use of patterns. The $L P$ travel guides considered are Argentina (2016), Chile \& Easter Island (2012), Germany (2016), Greece (2016), Rome (2016), Spain (2016), The Netherlands (2016) and USA (2016). The RG travel guides considered are Bahamas (2007), Montenegro (2009), Pyrenees (2007), Tuscany \& Umbria (2006), Venice \& the Veneto (2007), The Philippines (2007), Montréal (2007), Peru (2009), and Romania (2008).

Likewise, examples are taken from a corpus covering all travel writing titles on Portugal and Spain originally published within the period 1986-2003, studied from different perspectives elsewhere (Bento, 2018; 2019):

Arencibia, Franck (2003), Spain: Paradox of Values/Contrasts of Confusion. A Foreigner's Personal Perspective, New York, iUniverse.

Cela, Camilo Jose (1986), Nuevo Viaje a la Alcarría, Barcelona, Plaza \& Janes.

Evans, Polly (2003), It's not about the Tapas. A Spanish Adventure on Two Wheels, London, Bantam Books.

France, Miranda (2001), Don Quixote's Delusions. Travels in Castilian Spain, London, Phoenix.

Hewitt, Richard (1999), Uma Casa em Portugal, Lisboa, Gradiva (originally published as: A Cottage in Portugal (1996), London, Simon \& Schuster).

Hyland, Paul (1996), Backwards out of the Big World. Voyage into Portugal, London, Harper Collins.

Llamazares, Julio (1998), Trás-os-Montes. Uma Viagem Portuguesa, Lisboa, Difel.

Proper, Datus C. (1992), The Last Old Place. A Search through Portugal, London, Simon \& Schuster.

Stewart, Chris (1999), Driving over Lemons. An Optimist in Andalucia, New York, Phanteon Books.

\section{The presentification of the past}

In the 2016 ebook edition of LP Argentina one reads that the "subtle broodiness" of Argentineans:

stems from a pessimism they've acquired watching their country, one of the world's economic powerhouses during the late 19th and early 20th centuries, descend into a morass of international debt. They've endured military coups and severe government repression, while witnessing their beloved Argentina plundered by corrupt politicians. (Lonely Planet Argentina, 2016: 588)

Argentineans are presented here as the living people the traveller may find in the contemporary country and at the same time as the previous generations. They are defined as the people who ever lived within "Argentina", a political entity that has existed under such designation only since the $19^{\text {th }}$ century. The definition thus 
ignores that the name is one of the few aspects of the polity and of the corresponding society that remained unchanged over the period. In doing so, it forgets that most probably Argentina in the $19^{\text {th }}$ century had more in common with, say, the United States of the time, than with the $21^{\text {st }}$ century Argentina the travel guide is supposed to be about.

The excerpt above is a case of presentification of the past: mentioning past events or states of affairs having as pretext the fact that an author is at or making reference to a place where such events or states of affairs took place. ${ }^{2}$ Within travel guides, besides examples as the one above, sections titled "History" or similar are typical cases of presentification. One can find them in all $L P$ editions considered by this study and they are part of many RG editions (Philippines, Montréal, Peru, Romania), suggesting the pattern is a staple of the genre.

To be sure, in some cases the pretext is a causal connection to contemporary events or state of affairs, so that those cases are not presentification (albeit causality is at times problematic, as developed below). Most of the time, though, causality is absent. In LP Argentina, descriptions of people who lived in the region before the arrival of the Spanish and references to human arrivals 10,000 BC do not help much explaining present days, and are seemingly included only because they took place within a territory that later would be called Argentina. Their influence is minimal considering the History of the territory afterwards, that is, millenniums of cultural and genetic evolution and the recent arrival of new genes and cultures (first, colonizers; later, migration). In this way, presentification performs an implicit regression to the infinite, making time irrelevant: because two things happened or state of affairs existed within a given space, they are treated as inextricably bounded.

Presentification is also frequent in travel writing, in a variety of types. Heritage as pretext, a most common type, can be seen in the text of Paul Hyland (1996). On page 168 he is aboard a train, describing passengers; seeing a castle though the window, he provides a history of the monument in two lines and goes back to describing passengers without further mention it. A similar, also frequent, type is presentless presentification, which consists in talking about the past of a place just because one has arrived there (e.g. Hyland, 1996, describing the city of Évora: 171-173), dispensing altogether with contemporary references as pretext.

The pretext may be even looser, resulting in equivalents to the "History" section of travel guides. In such presentification, travel writers shed the observable present as motif to write about the past, simultaneously ignoring place; instead, they base themselves on the whole space their book is about, often indicated in titles and subtitles. Hyland thus starts his chapter 20 by mentioning historical events around a $16^{\text {th }}$ century King, mentioning voices that see the monarch's death in a ill-prepared battle as an escape from marriage. Only several pages later Hyland makes a transition to the present (before returning to the $16^{\text {th }}$ century, where the chapter ends):

2 This definition means that human tourist guides' talks about History are also cases of presentification of the past. 
Sebastiao looked for a best man to escort him to the wedding. On that night in the spring of 1578 he waited for him in Jeronimos. In May 1995 Dom Duarte, [...] pretender to the throne, waited there $[\ldots]$ for the hand of $[\ldots]$ Isabel $[\ldots]$ de Heredia.

By arranging his writing in this way (several of his chapters follow such structure), Hyland is resorting to a practice usual in travel writing. Similarly to the example of the Argentineans, he starts from the fact that he is travelling within a polity called Portugal. As this polity has existed under that name for around 800 years (bar an interruption of a few decades), he considers that it has somehow been the same throughout the period. Therefore, he sees it worth mentioning any historical events that took place within the polity, irrespective of their relation to the states of affairs and events of the Portugal in which he is travelling.

Place is thus absent as motif and space is associated with an entity in a problematic way (for example, during the first decades after independence, the territory of Portugal expanded significantly by conquest, so that not even the whole space to which Hyland's book refers to remains the same, as invariably happens throughout History). This is a case similar to one found in Datus Proper, when planning his journey:

Adriano [a friend] and I will therefore jump back and forth from now [...] to earlier times. We will do this [...] because there is no other way to see the country. [...] we will also visit the fifteenth century in Sagres, the fourteenth in Aljubarrota, and the second century B.C. in Viseu. (Proper, 1992: 30)

Another type of presentification, the anthropomorphological one, comes about at the beginning of Hyland's text, where he sets the goal for his journey:

[...] find out how Portugal - [...] founder of the first modern empire and, once, the richest country on earth - gets on with being not great any more. [...] Left on the shelf at Europe's edge, Portugal has had to [...] flutter its eyelashes at Brussels. I'm going upriver [...] as far as Alcántara in Spain, to find out where Portugal begins and ends. If it's lost its role and its riches, at least can be not-Spain. (Hyland, 1996: 10)

Here, Portugal is more than a territory, a polity and a name, being presented as an immutable, conscious entity suffering identity crisis, to which a kind of postmodernist différence is proposed as remedy (being not-Spain).

Finally, in Miranda France's text one finds fiction-based presentification. As usual, physical presence in a place (the region of Castille) is a pretext for talking about its past (4.5\% of words). Then France dives into the realm of Cervantes's Don Quixote with references, quotations, summaries and comments on the book and on its author $(16 \%)$, making the frailty of pretext extreme: had Cervantes located Quixote's adventures, say, in the neighbouring region of Aragon, it would make no sense at all to deal with the theme within a book subtitled Travels in Castilian Spain. 


\section{The specific appeal of presentification}

In these forms, the pattern occupies a large extension of the travel writing considered: albeit three works do not show it, it covers between $15 \%$ and $34 \%$ of each of the other texts. ${ }^{3}$ How to account for such presence? The question is relevant because travel writing is supposedly underpinned by direct experience, and at least in placeless presentification (that which is found in "History" sections) such defining element is missing. As regards travel guides, a similar perplexity arises: if readers make use them before and during a journey, why does the genre include so much History loosely related to what readers actually experience if they become visitors?

Part of the appeal of the pattern may be based on the outright lure of the past: Stanford (1995 [1994]: 52-53) sees History as "protest against time and death" and holds that it provides a sense of a common Humanity. The past may also provide distinction: because it is insubstantial in that it cannot be physically reached, it might play a role in the satisfaction of Urry's (2002 [1990]) romantic gaze or the "romantic desire for positional goods" that Walter (1982: 303) associates with the middle class. When one can go almost anywhere by travelling or via the media, perhaps the ultimate exotic is the past, which one can not touch. For example, following the massification of Peter Mayle's travel writing on Provence, Lady Fortescue's More Perfume from Provence (Fortescue, 2016 [1935]) became the middle class's new talisman of rural France (Sharp, 1999: 216). "Removed in time as well as in space", it constructs "a true positional good that cannot be obtained and so cannot become passé" (idem).

While presentification can be postmodern in its arbitrary motif for the use of the past, it also functions as a modern mechanism by providing certainty. As Featherstone (1995: 107) notes, the past has been seen in different historical periods as "the epitome of coherence and order, something which was more simple and emotionally fulfilling, with more direct and integrated relationships". A door is thus opened to traditional society (Tönnies, 1887), in which people find meaning lost in modernity (MacCannell, 1999 [1976]: 91).

But although MacCannell sees this performed through tourism - travelling in space - presentification allows readers to achieve it by travelling in time. The past helps people recover the lost "sense of place" of pre-industrial context (Walsh, 1992: 12), "an attachment to, or knowledge of, one's locality, an understanding or appreciation of the processes which have affected a place". According to Walsh this has been replaced by disembedding (a notion originally proposed by Giddens, 1990), consisting in a distantation from the local realm and the developments which affect people's lives. Broader, similar notions have been proposed under labels colonization of the lifewold (Habermas, 1984 [1981]; and Weber, 2005 [1905]: 123) iron cage.

Broadly, for one who is not aware of the constant rewriting of History, the past represents safety because it is by definition completed. As Schlesinger (1971: 339-357)

3 The value for Cela was first worked out by Bento (2017). 
puts it, historians endow it "with an ordered clarity contrasting with the chaos or imprecision of their own times", so that the past may help allaying anxiety regarding the "existential/anchoring of reality" (Giddens, 1991: 38). In this sense, the past becomes the typical modern grand narrative, "the overarching 'story line' by means of which we are placed in history" (Giddens (1990: 2, refering to Lyotard, 1984).

Heritage, for example, is usually transformed only by the long run work of erosion and it is prone to be frozen for good by (recurrent) renewal. According to Strong (1978: 46-47), it conveys "some kind of security, a point of reference which [...] seems stable and unchanged" in face of the "problems and troubles, of changes within the structure of society, of the dissolution of old values and standards". It was probably such appeal that led Portuguese Literature Nobel Prize José Saramago, a Communist Party member, into ignoring the world of work in his (1981) Viagem a Portugal (Journey to Portugal), and presenting a country solely made of palaces, castles and other monuments (Matos, 1999: 485).

Within tourism, presentification offers ways through which people escape problems and find rewards within Iso-Ahola's (1982) model of motivation, because a presentified past enables them to engage with the "'real [past] life' of others" (MacCannell, 1999 [1976]: 91). Within Cohen's (1979) phenomenology of tourist experiences, presentification may cater for the experiential tourist (alternative meanings in past otherness), the experimental tourists (sampling different past life styles) and existential mode (cognitive connections with bygone otherness).

Finally, authors face practical incentives for using the past within travel writing and travel guides. A first incentive is that History provides ready-made information related to their subject. One of the motifs why author Chris Stewart does not engage in presentification is probably that his account is set in a Spanish region on which there are not much History books in English or translated into English (Stewart claims not to be fluent in Spanish upon arrival). Second, in contrast to written History, indirect information about the present (that is, not gathered by experience) is quite dispersed in its physical and electronic locations, while the density of contemporary people, events and trends with major impact is lower, as it competes with all that has previously happened. All in all, History enables travel writers and travel guide writers more choice in catering for an intended audience.

In turn, the audience of travel writing and travel guides usually reads about a past made of individuals. Queens, kings, great politicians or common people who take actions with major impact are the staple of the "Grand" History often found within these genres, as in Hyland and Proper. A more abstract and complex socio-cultural History encompassing the interplay between agency, groups, material circumstances, social relations, chance, etc., is often absent, facilitating the identification of readers with the past and enhancing the appeal of the genres. In addition, while in History texts the past is the obvious theme, demanding intellectual commitment, in travel writing and travel guides it shows up en passant as the theme is a spatial entity, thus making for a lighter (postmodern) reading. 


\section{Synecdocal imagination, inconsequential social and fragile social causality}

Three other astheticisation patterns not necessarily related to the past are found in the texts under analysis. A first one, synecdocal imagination, can be seen when author-protagonist Richard Hewitt hires a local worker to help renovating a house. Upon verbal agreement, Hewitt is offered a cigarette. Assuming this to be part of a ritual necessary to seal the deal, he mimics the worker by inhaling smoke, throwing the cigarette to the ground and stepping on it (page 77). A similar attitude is shown by author Polly Evans when she arrives at a house where she had booked a room (page 40): seeing the surprise of the owner when she apologizes for being "so late", the Evans makes sense of such reaction by mentioning lack of punctuality as a cultural trait.

In these excerpts, characteristics of society are called upon to understand and/or explain particular circumstances. The pattern fit Frow's view (1991: 125) that for the tourist, "a place, a gesture, a use of language are understood as suffused with ideality [...] giving on to the type of the beautiful, the extraordinary, or the culturally authentic". As Di Betta (2014: 88) notes, in order to make sense of their experiences tourist "apply upon objects a synecdoche-type transformation, according to which the part (the object) is made to represent the whole (the culture) by extension".

Synecdocal imagination is therefore analogous to sociological imagination, "the vivid awareness of the relationship between experience and the wider society" (Mills, 1959). However, in the synecdocal imagination there is no concern about the validity of the generalisation. A mere recognition of a priori assumptions takes place, so that the process does not even amount to rhetorical induction (Edmondson, 1984:12), where an accumulation of examples tries to persuade readers about general propositions. Instead, it arguably amounts to a postmodern attitude in its playfulness and dismissal of the need to present founded knowledge.

A second pattern is called inconsequential social. It consists in information about the social world which provides no relevant knowledge, thus opposing grand (explanatory) narratives and therefore amounting again to a postmodern attitude (Lyotard, 1984). Irrelevance stems from lack of context/comparison or other type of missing information (in contrast to synecdocal imagination, where context is somewhat in excess). A frequent case is the quotation of statistics without contextualisation in a time series or a cross section analysis, as seen frequently in author Frank Arencibia, leading the reader to wonder, e.g., whether the values at hand are high or low relative to other countries or previous years. In general, the inconsequential social prompts questions such as "Is this a case of what?" or "So what?" In some situations a reply might be possible, but only applying, e.g., a large dosis of synecdocal imagination through a long-chain reasoning.

Author Camilo Jose Cela shows the workings of the inconsequential social by playing with it. After describing a practice involving a suspended cock that is hit by a man on a horse, an unknown voice says "They do that in many villages"; to this, Cela replies "But now I am going through this one" (my translations). Here, Cela 
makes his description loose relevance by visibly ignoring the context for which the unknown voice seems to be calling - which in turn could call for a comparison, an account of common origins, etc.

By thus ironising with knowledge conventions, Cela is arguably being postmodern. Albeit postmodernism does not necessarily underlie all instances of the inconsequential social, one finds in this author a typically postmodern subtype: the isolated description. When Cela names several types of honey produced in Alcarría region (Cela, 1986: 202) without further information, probably the reader would like to know about differences, if production is for subsistence or market oriented, etc. Likewise, Hyland (1996: 64) depicts two youngsters kissing in a public space without comment, presenting a fragment and providing a signifier without meaning. This is characteristic of postmodern culture in that postmodern culture results from the "transformation of reality into [mere] images" (Jameson, 1983: 125, quoted in Plummer and Nehring, 2014: 180). Arguably, a reaction of many a (modern) reader to Hyland's isolated description would be to ask whether the author is conveying a picture of a tendency. Similar comments apply, still in Hyland, to a description of a teenage girl wearing a Campaign for Nuclear Disarmament badge (Hyland, 1996: 128), that only with further assumptions, possibly implying synecdocal imagination, could be considered a comment on (the Portuguese) society.

A third pattern is called fragile social causality. It consists in connecting two situations - at least one of which has a social dimension - by a suggestion of causality that is unfounded, unclear, unlikely, and/or impossible, thus performing a postmodern indistinction between valid and invalid knowledge. This definition implies that the causal form of presentification, perhaps the most frequent one, is a particular case of fragile causality, as in the example of the "subtle broodiness" of Argentineans. Such causal form is akin to causal History in that events/states of affairs influence subsequent events/states of affairs, but there are important differences: first, History usually focus on a given period, while causal presentification potentially considers the whole past as explanatory factor of the present of a place; second, and crucially, in the causal presentification of the past the validity of the proposed causal connection does not appear as important.

Another example of fragile causality amounting to causal presentification is found in the magazine The Economist. The September 30th 2017 edition contains an article titled: "Iran's Kurds are growing restless, too" where one reads: "Were Iranian Kurds to start a serious revolt, Iran's forces would have the upper hand. It took but a few months for them to smother the Mahabad Republic in 1946". The same reasoning underlies sports forecasts based on past results, ignoring that only teams names remain and that players change (one could easily replace Kurds for Kurdish team, Iranians for Iranian team and conflict for match).

Fragile causality, though, is not always related to the past. In My Invented Country: A Memoir, Isabel Allende claims that Chileans are very religious and adds that "The spiritual compulsion raises from the Earth itself: a people who live amid mountains logically turn their eyes toward the heavens" (Allende, 2004: 58). This causality is obviously problematic because, first, it is not clear why people would 
tend to look upwards because of the mountains. Second, granted they did so, in what measure that would foster religion? Finally, migrations of Spaniards and other people to the territory are ignored as possible causes of the "spiritual compulsion".

Others cases of the pattern are part of travel guides and journalism, genres where non-fictional expectations are probably even higher. The 2016 Lonely Planet ebook Edition on Greece claims that

it is easy to understand how so many myths of gods and giants originated in this vast and varied landscape, with wide open skies and a sea speckled with islands, where days melt from one to the next while you relish the white-sand and Palm-fringed beaches. (Lonely Planet Greece, 2016 ebook: 4)

Here, the reader is obliged to make strong assumptions regarding the powers of nature in order to accept that myths stem from characteristics of landscape. A similar flaw is found in the July 15th 2017 edition of The Economist (article "Call of the wild - Why women are so keen on swimming") that reviews two books on the sport:

Treading water, sinking like a stone or riding the wave: there is something about water that makes it a good metaphor for life. That may be one reason why so many find solace in swimming when life's seas get rough.

In this case one can note both inconsequential social and fragile causality. The claim that many people resort to swimming in the face of trouble does not consider the possibility that what is relevant might be a more general engagement with sport, hobbies or other activities in order to forget problems. In addition, the expression "many people" would need to be contextualised (e.g. by comparing the number of people reacting to hardship by swimming with the number of people reacting by doing other activities). Inconsequential social is thus produced: "Many find solace in swimming when life's seas get rough - so what?" At the same time, the excerpt involves fragile causality in the strong subjectivity of the assumption that water is a good metaphor for life and the in the very causal power of water as good metaphor for life.

Another instance of this causal black box is presented in the 2012 LP ebook Edition on Chile $\mathcal{E}$ Easter Island. On page 2 one reads that "close borders foster intimacy. No matter where you go, it feels a little like a backyard". The text then mentions (same page) that Chile averages $175 \mathrm{~km}$ in width, so that "you start greeting the same faces". The process through which narrowness leads intimacy and repeatedly finding people is not clear, seemingly ignoring that Chile stretches North-South for more than 4,000 km and had more than 15 million inhabitants in 2012. Likewise, in the LP Discover Italy 2014 edition (page 6), the Mediterranean diet is proposed as cause for the claim that "Italy wears its millennia of turbulent history extraordinarily well" (which refers to the fact that ancient towns like Pompeii and Herculaneum are well preserved). 


\section{The appeal of the aesthetic cognition of society}

With the benefit of the examples above, it is now possible to propose a more detailed definition of aesthetic cognition of society as substantiated in the patterns and discuss the appeal of the practice by considering some of its functions. First, aestheticisation means here, in general terms, the same as for Eagleton (1990: 406) quoting and discussing of Habermas (Dews, 1986: 127): "His intention [...] is 'not to mix questions of truth with questions of justice or taste' - to resist, in short, that wholesale aestheticisation of the social [...] typical of some postmodern thought".

Second, for Eagleton (1990: 366), aesthetic is also "what [...] we find attractive". In this article attractive is understood in a broad sense (e.g. art that may interest people for its very repulsiveness). The specificity of attraction in aesthetic cognition of society lies in that the latter is made of intellectual processes related to social reality performed by writers and readers. This establishes the crucial difference between aesthetic cognition and non-aesthetic cognition that the latter is not necessarily attractive.

Third, as regards the relations to social reality, the patterns can be said to be alike aestheticisation performed by the flâneur. This figure has been identified "with a certain kind of fluid, aestheticised sensibility that implies the abdication of political, moral or cognitive control over the world" (Gluck, 2003: 53), and the dismissal of the validity/relevance of knowledge fits such abdication. In addition, both aesthetic cognition of society and flânerie (which might have performed postmodernism avant la lettre) correspond to a similar notion of the aesthetic as:

[a] recognition of the continuity between experiences of fine art and experiences from other domains [...]. [...] objects and activities not essentially connected to art or nature can have aesthetic properties and/or that they can give rise to significant aesthetic experiences. (Davies et al., 2009: 136)

The notion of postmodernism proposed by Urry (2002 [1990]: 74) is a case of this continuity. It consists in a dissolution of the boundaries between high and low cultures and cultural forms such as tourism, art, education, photography, television, music, sport, shopping and architecture. A first role of the aesthetic cognition of society can now be envisaged as a way of performing the tourist gaze, which is "increasingly bound up with, and as partly indistinguishable from all sorts of other social and cultural practices" (idem).

Within the aesthetic cognition of society, the tourist gaze shows important specificities. What could be called aesthetic gaze involves indistinctions between notions of valid/invalid knowledge on society, relevant/irrelevant knowledge and broadly between science, art, entertainment and tourism. Gaze should here be taken metaphorically given it is performed through reading, showing how the tourist gaze can go beyond visual consumption (Urry mentioned this possibility but did not developed it).

In addition, this aesthetic gaze is performed remotely, shedding a new light on the appeal of travel, expressed by de Botton (2002: 246) as a mindset which 
enables one to "find a supermarket or hairdressers unusually fascinating", and which Urry (2002 [1990]: 1) presents as the interest and curiosity that people direct towards their environment when they "go away". To be sure, such mindset probably stems in many cases from the sheer awareness of being elsewhere, within otherness. Adapting Costa's (2002: 24) conceptualisation of hallmark events such as the 1998 Lisbon World Exposition, the feeling of "direct experience" or the possibility of testifying that one has "been there" (with the bonus of enabling conspicuous consumption) are important underlying motifs.

However, the fact that travel writing titles achieve at times significant sales suggests that the appeal of travel is not always dependent on "corporeal proximity, [which] makes [travel] necessary and desirable" (Urry, 2002 [1990]). Moreover, travel writing titles often achieve commercial success in the very countries they deal with, hinting that readers are also interested in their own societies and not always need "to go away". As de Botton (2002: 246) concludes from his reading of Xavier de Maistre's (1994) Voyage around My Room, "the pleasure we derive from journeys is perhaps dependent more on the mindset with which we travel than on the destination we travel to". The patterns are thus indicators of a travel-related mindset that may dispense with physical contact with otherness and with otherness altogether, albeit not with a supposedly existing society (which differentiate the patterns from fiction and exercises such as de Maistre's).

Seeing aesthetic cognition of society through Cohen's (1995) notion of postmodern tourism leads to another role of the patterns: providing playfulness to readers. Albeit not explicitly dealing with the indistinctions between notions of valid/invalid and relevant/irrelevant knowledge, Cohen uses the term postmodern tourism to highlight tourist's "playful search for enjoyment or an aesthetic enjoyment of surfaces" (Cohen, 1995: 21). In the patterns, the playful dimension can be seen in cognitive carelessness and, specifically, in the fact that there is deception but no obvious intention to deceive on the part of authors for immediate, direct self-gain at the expense of readers. ${ }^{4}$

At the same time, the patterns can be a mean to escape modernity by reading about a supposedly authentic pre-modernity (the " 'real life' of others", as per MacCannell (1999 [1976]: 91), which can be found in descriptions of the contemporary and of the past. Given the patterns fit MacCannell's and Cohen's types of tourists and that these fit Iso-Ahola's model of tourist motivation, they make Iso-Ahola's model more concrete. Specifically, they allow tourists to enhance their ego and prestige, in as much as the underlying cognitive relations may provide a feeling of mastery over otherness and the possibility of boasting about those relations upon reading (thus enabling conspicuous consumption without corporeal proximity).

In addition, still within Iso-Ahola's model, the patterns enable tourists to escape personal and interpersonal troubles in ways other than merely entering in a relaxation mode and that are not dependent on the isolation provided by physical

4 In this sense, authors are still being "honest in their textual renderings of their experiences and, more generally, of their presentation of otherness", as Bento (2019) comments elsewhere on the travel writing texts considered in this study. 
distance from primary and/or secondary social groups (which requires "going away"). Paradoxically, then, the social dimension of personal routine is diluted and replaced by cognitive relations to society, amounting to an escape from interpersonal relations on an individual to individual basis.

Finally, and similarly to what was as argued concerning presentification, the aesthetic cognition of society enables a relation with society that may, within Cohen's phenomenology, interest the experiential tourists looking for meaning, the experimental tourists looking for alternative ways of living and even the existential tourists looking for stronger connections with otherness.

\section{Conclusion}

This study presented evidence of some patterns deemed postmodern through which travel writers, travel guide writers and other writers enable tourists and would-be tourists to engage cognitively with society, an addition to the interpersonal relations usually considered in literature as a motivation for tourists.

The rationale for the use of the indirect evidence of texts instead of direct surveys to capture tourists motivations and meanings is reinforced in hindsight. People directly surveyed most probably would be unable/unwilling to express/recognize a major finding of the study: travel writing and travel guides (and other genres) often contain aesthetic cognitive relations to society. Another argument for using texts is that, albeit patterns as those observed may be found outside texts, they are probably more visible and performed in more complex ways within texts. Arguably, even if such complex ways are enacted (as opposed to merely thought) by individuals directly surveyed, they would not be easily identified.

The focus on travel writing questioned its very identity. First, aesthetic cognition of society was found within a genre that mostly presents itself as factual; second, through presentification, the past has often a very significant presence within a genre that is supposed to be an account of a contemporary journey. The presence of the patterns in travel guides makes these prone to similar criticism, as they are expected to help organizing a journey to a contemporary space, and to provide factual views on that space. Examples considered within the genres memoir and journalism suggest that the use of the aesthetic cognition of society may be widespread and outline avenues for future studies.

Reasons were discussed for the high frequency of presentification of the past. These included the availability of ready-made information in written History and nostalgia for a past seen as safer and solid. In addition, being insubstantial in as much as it cannot be reached, the past satisfies a desire for positional goods and avoids (mass) tourism, making it possible to enact the romantic tourist gaze proposed by Urry; moreover, it may foster ego-enhancement and prestige, in itself or as conspicuous consumption.

The patterns were also shown to be elements of influential models in tourist motivation proposed by Iso-Ahola, Cohen, MacCannell. It was suggested that they may be buildings blocks of the tourist gaze as proposed by Urry, enabling relations 
with society that go beyond the visual consumption of the gaze (Urry, 2002 [1990]). In addition, it was proposed that the patterns may be part of a larger, typically postmodern tendency for indistinction between fiction and non-fiction; art and science; and tourism and other activities - fitting both the tourist gaze and Cohen's postmodern tourism. Hence, one could consider in future studies whether they are frequent in text deemed chronologically previous to postmodernism - possibly reinforcing criticism on the periodisation of postmodernism.

At the same time, it was shown how the patterns may be relevant in a modern context, as they may be elements of MacCannell's model of search for authenticity lost in modernity. In addition, it was also seen that the relations involved in the patterns are fundamentally different from the interpersonal relations on an individual to individual basis of the daily life, fitting Iso-Ahola's (1982) escape-seeking model of tourist motivation.

All in all, the patterns allow people to establish indirect contact with and even learn about otherness - albeit in a characteristically postmodern way in which validity of knowledge does not seem to be relevant. This creates important practical and ethical consequences, as representations have strong influence in shaping views of people(s) and attitudes and behaviours towards people(s). Such consequences are made more relevant considering that, taken together, the patterns account for a society/culture in a quite complete manner in terms of dimensions covered. Not only they encompass both past and present, but they also deal with the agency-structure frameword (even if most readers are not aware of the distinction): while presentification renders the strength of agency through historical figures such as power holders or heroes, shown as acting to a great extent independently of social forces, the other patterns render these forces in some cases.

\section{References}

Allende, Isabel (2004), My Invented Country. A Memoir, London, Harper Perennial.

Arencibia, Frank (2003), Spain. Paradox of Values/Contrasts of Confusion. A Foreigner's Personal Perspective, New York, iUniverse.

Bento, Paulo Tiago (2017), “Substantial authenticity, (post/)modernity and transformation of otherness: the second trip of Camilo José Cela to the Alcarria", Journal of Tourism and Cultural Change, 15(1): 37-58.

Bento, Paulo Tiago (2018), "Representations of Iberia at the turn of the 21st century in travel writing and social science: a quantitative approach", Análise Social, 228, pp. 598-623.

Bento, Paulo Tiago (2019), "Conditions of contact with otherness and their consequences: a quantitative analysis of contemporary travel writing on Portugal and Spain", Journal of Tourism and Cultural Change, 17(2): pp. 132-149.

Baudrillard, Jean (1994), Simulacra and Simulation, Ann Arbor, University of Michigan Press.

Cela, Camilo Jose (1986), Nuevo Viaje a la Alcarría, Barcelona, Plaza \& Janes. 
Clarke, David (2014), "Postmodern geographies and the ruins of modernity", in Stuart, Aitken, and Gill Valentine (Eds.), Approaches to Human Geography. Philosophies, Theories, People and Practices, London, Sage.

Cohen, Erik (1979), “A phenomenology of tourist experiences”, Sociology, 13 (2), pp. 179-201, accessed in: https://journals.sagepub.com/doi/abs/10.1177/003803857901300203 (last access in September 2020).

Cohen, Erik (1995), “Contemporary tourism trends and challenges: sustainable authenticity or contrived post-modernity", in Richard Butler and Douglas Pearce (Eds.), Change in Tourism. People, Places, Processes, London, Routledge.

Costa, António Firmino da (2002), “Identidades culturais urbanas em época de globalização", Revista Brasileira de Ciências Sociais, 17 (48), pp. 15-30.

Dann, Graham (1981), “Tourist motivation an appraisal”, Annals of Tourism Research, 8 (2), pp. 187-219, accessed in: https://www.sciencedirect.com/science/article/pii/ 0160738381900827 (last access in September 2020).

Davies, Stephen, et al. (Eds.) (2009), A Companion to Aesthetics, Malden, MA, John Wiley \& Sons.

de Botton, Allain (2002), The Art of Travel, New York, Pantheon.

de Maistre, Xavier (1994), Voyage around My Room. Selected Works of Xavier de Maistre (vol. 791), New York, New Directions Publishing.

Dews, Peter (1986), Jurgen Habermas. Autonomy and Solidarity, London, Verso.

Di Betta, Pablo (2014), "Authenticity as a mental state: a primer", Annals of Tourism Research, 47, pp. 86-88, accessed in: https://www.cabdirect.org/cabdirect/ abstract/20143249594 (last access in September 2020).

Eagleton, Terry (1990), The Ideology of the Aesthetic, Maiden, MA, Blackwell.

Eco, Umberto (1985), Reflections on The Name of the Rose, London, Secker and Warburg.

Economist, The (2017a), "Call of the wild: why women are so keen on swimming", July 15th, accessed in: https:/www.economist.com/news/books-and-arts/ 21724978-all-skinny-dipping-why-women-are-so-keen-swimming (last access in September 2020).

Economist, The (2017b), “Iran's Kurds are growing restless, too", September 30th edition, accessed in: https://www.economist.com/news/middle-east-and-africa/ 21729790-referendum-held-iraqi-kurds-revving-up-their-iranian-cousins-irans-kur ds (last access in September 2020).

Edmondson, Ricca (1984), Rhetoric in Sociology, London, Macmillan.

Evans, Polly (2003), It's not about the Tapas. A Spanish Adventure on Two Wheels, London, Bantam Books.

Featherstone, Mike (1995), Undoing Culture. Globalization, Postmoderism and Identity, London, Sage.

Fortescue, Lady Winifred (2016 [1935]), More Perfume from Provence, Auckland, Pickle Partners Publishing.

France, Miranda (2001), Don Quixote's Delusions. Travels in Castilian Spain, London, Phoenix.

Geertz, Clifford (1973), The Interpretation of Cultures, New York, Basic Books.

Giddens, Anthony (1990), The Consequences of Modernity, Stanford, Stanford University Press. 
Giddens, Anthony (1991), Modernity and Self-Identity. Self and Society in the Late Modern Age, Stanford, Stanford University Press.

Gluck, Mary (2003), "The flaneur and the aesthetic: appropriation of urban culture in mid-19th-century Paris", Theory, Culture E Society, 20 (5), pp. 53-80, accessed in: http://journals.sagepub.com/doi/abs/10.1177/02632764030205003 (last access in September 2020).

Habermas, Jurgen (1984 [1981]), Theory of Communicative Action, London, Heinemann. Hewitt, Richard (1999), Uma Casa em Portugal, Lisboa, Gradiva (originally published as A Cottage in Portugal, London, Simon \& Schuster, 1996).

Hutcheon, Linda (1980), Narcissistic Narrative. The Metafictional Paradox, New York and London, Methuen, Wilfrid Laurier University.

Hyland, Paul (1996), Backwards out of the Big World. Voyage into Portugal, London, Harper Collins.

Iso-Ahola, Seppo (1982), “Toward a social psychological theory of tourism motivation: a rejoinder", Annals of Tourism Research, 9, pp. 256-262, accessed in: https://www.sciencedirect.com/science/article/pii/0160738382900494 (last access in September 2020).

Jameson, Fredric (1983), "Postmodernism and consumer society”, in H. Foster (Ed.), Postmodern Culture, London, Pluto Press.

Li, Mimi, Hanqin Zhang, and Liping A. Cai (2016), "A subcultural analysis of tourism motivations", Journal of Hospitality \& Tourism Research, 40(1): pp. 85-113.

Llamazares, Julio (1998), Trás-os-Montes. Uma Viagem Portuguesa, Lisboa, Difel.

Lyotard, Jean-François (1984), The Postmodern Condition. A Report on Knowledge, Minneapolis, University of Minnesota Press.

Lyotard, Jean-François, and Brian Massumi (1986), “Rules and paradoxes and svelte appendix", Cultural Critique, 5, pp. 209-219, accessed in: https://www.jstor.org/stable/1354362 (last access in September 2020).

MacCannell, Dean (1973), "Staged authenticity: arrangements of social space in tourist settings", American Journal of Sociology, 79 (3), accessed in: https://www.journals.uchicago.edu/doi/abs/10.1086/225585 (last access in September 2020).

MacCannell, Dean (1999 [1976]), The Tourist. A New Theory of the Leisure Class. Berkeley and Los Angeles, University of California Press.

Malinowski, Bronlislaw (2005 [1922]), Argonauts of the Western Pacific. An Account of Native Enterprise and Adventure in the Archipelagoes of Melanesian New Quinea, London, Taylor \& Francis.

Matos, Jacinta (1999), Pelos Espaços da Pós-Modernidade. A Literatura de Viagens Inglesa da Segunda Grande Guerra à Década de Noventa, Porto, Afrontamento.

Mercille, Julien (2005), "Media effects on image: the case of Tibet", Annals of Tourism Research, 32 (4), pp. 1039-1055, accessed in: https://www.sciencedirect.com/science/article/pii/S0160738305000782 (last access in September 2020).

Mills, Charles Wright (1959), The Sociological Imagination, Oxford, Oxford University Press. Plummer, Ken, and Daniel Nehring (2014), Sociology. An Introductory Textbook and Reader, Londres, Routledge. 
Proper, Datus C. (1992), The Last Old Place. A Search through Portugal, London, Simon \& Schuster.

Ross, Elizabeth, and Seppo Iso-Ahola (1991), “Sightseeing tourists' motivation and satisfaction", Annals of Tourism Research, 18, pp. 226-237, accessed in: https://www.sciencedirect.com/science/article/pii/016073839190006W (last access in September 2020).

Santos, Carla (2004), "Framing Portugal: representational dynamics", Annals of Tourism Research, 31 (1), pp. 122-138, accessed in: https://www.sciencedirect.com/science/ article/pii/S0160738303001087 (last access in September 2020).

Saramago, José (1981), Viagem a Portugal, Lisbon, Caminho.

Schlesinger, Arthur (1971), “The historian as participant", Daedalus, 100, pp. 339-357.

Sharp, Joanne (1999), "Writing over the map of Provence: the touristic therapy of 'A Year in Provence'", in James Duncan, and Derek Gregory (Eds.), Writes of Passage. Reading Travel Writing, London, Routledge.

Stanford, Michael (1995 [1994]), A Companion to the Study of History, Oxford, Blackwell.

Stewart, Chris (1999), Driving over Lemons. An Optimist in Andalucia, New York, Phanteon Books.

Strong, Roy (1978), Recreating the Past. British History and the Victorian Painter, New York, Thames and Hudson.

Tönnies, Ferdinand (1887), Gemeinschaft und Gesellschaft, Leipzig, Fues.

Urry, John (2002 [1990]), The Tourist Gaze, London, Sage (second edition).

Walsh, Kevin (1992), The Representation of the Past. Museums and Heritage in the Post-Modern World, London, Routledge.

Walter, J. Anthony (1982), “Social limits to tourism”, Leisure Studies, 1 (3), pp. 295-304, accessed in: https://www.tandfonline.com/doi/abs/10.1080/02614368200390241 (last access in September 2020).

Weber Max (2005 [1905]), The Protestant Ethic and the Spirit of Capitalism, London and New York, Routledge.

Paulo Tiago Bento. Professor adjunto, Universidade Federal do Sul da Bahia. E-mail: paulobento@ufsb.edu.br

Receção: 13 de novembro de 2018 Aprovação: 11 de outubro de 2019 